Alessandra Rusconi

Heike Solga

\title{
A Systematic Reflection upon Dual Career Couples
}

Discussion Paper SP I 2008-505

October 2008

Social Science Research Center Berlin (WZB)

Research Area:

Education, Work, and Life Chances

Research Unit:

Skill Formation and Labor Markets

http://www.wzb.eu/bal/aam

E-mail: rusconi@wzb.eu

solga@wzb.eu 
Dieses Discussion Paper ist im Rahmen des Projekts "Gemeinsam Karriere machen" entstanden. Das Projekt wird vom Bundesministerium für Bildung und Forschung (BMBF) und vom Europäischen Sozialfonds für Deutschland (ESF) im Rahmen des Programms „Frauen an die Spitze“ von 2007 bis 2010 gefördert.
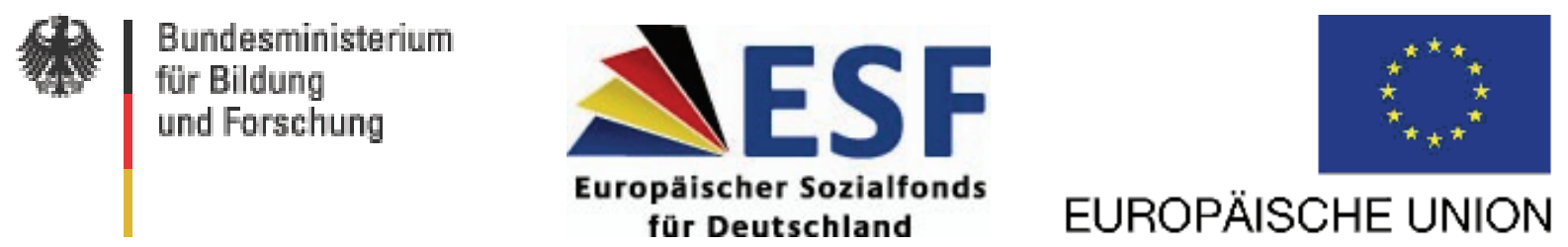

Suggested Citation/Zitierweise:

Alessandra Rusconi, Heike Solga

A Systematic Reflection upon Dual Career Couples

Discussion Paper SP I 2008-505

Wissenschaftszentrum Berlin für Sozialforschung (2008)

Social Science Research Center Berlin (WZB)

Research Area:

Education, Work, and Life Chances

Research Unit:

Skill Formation and Labor Markets
Wissenschaftszentrum Berlin für Sozialforschung gGmbH (WZB)

Forschungsschwerpunkt:

Bildung, Arbeit und Lebenschancen

Abteilung:

Ausbildung und Arbeitsmarkt

Reichpietschufer 50, D-10785 Berlin

Telefon: +49 30 25491-0, Fax: +49 30 25492-684

http://www.wzb.eu 


\begin{abstract}
Particularly among the highly educated, a persistent upward trend in female employment rates has characterized western industrialized countries in the last decades. Yet, strong gender inequalities persist in the career chances of equally highly qualified men and women. Women are still underrepresented in executive/leading positions in both the private and public sector of the economy. We argue that such gender inequalities are also due to the fact that the majority of highly educated women lives with an equally highly educated partner. For these women the realization of dual careers becomes ever more important and represents an essential prerequisite for their own professional development. Following Phyllis Moen's "linked lives" idea, we will argue that the achievement or failure of dual-career arrangements is a "social-relational process" (Moen 2003a: 10) and that partners' lives are embedded with and influenced by each other. In particular, we will discuss how this entwining occurs, which processes at different levels play a role, and how these different processes interact with each other. Finally, we will give some suggestions on the direction for future research.
\end{abstract}

\title{
Zusammenfassung
}

Vor allem bei Hochqualifizierten charakterisiert ein andauernder Aufwärtstrend weiblicher Beschäftigungsraten die westlichen Industrieländer in den letzten Jahrzehnten. Jedoch herrscht bei den Karrierechancen von gleich qualifizierten Männern und Frauen noch immer eine große Geschlechterungleichheit vor. Frauen sind in führenden/leitenden Positionen sowohl im privatwirtschaftlichen als auch im öffentlichen Beschäftigungssektor noch immer unterrepräsentiert. Wir argumentieren, dass solche Geschlechterungleichheiten auf den Umstand zurückzuführen sind, dass die Mehrzahl hoch gebildeter Frauen mit gleichermaßen hoch gebildeten Partnern zusammenlebt. Für diese Frauen gewinnt die Realisierung von Doppelkarrieren an Bedeutung und stellt eine entscheidende Voraussetzung für ihre eigene professionelle Entwicklung dar. In Anlehnung an Phyllis Moens „linked lives“ Idee werden wir diskutieren, dass der Erfolg oder das Scheitern von Doppelkarrierenarrangements ein "social-relational process" (Moen 2003a: 10) ist und dass die Lebensverläufe der Partner miteinander verwoben und voneinander abhängig sind. Im Einzelnen werden wir diskutieren, wie diese Verflechtung sich gestaltet, welche Prozesse auf verschiedenen Ebenen eine Rolle spielen und wie diese Prozesse miteinander interagieren. Zum Schluss werden wir Vorschläge für die Richtung zukünftiger Forschungen formulieren. 



\section{Contents}

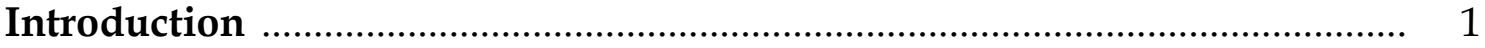

Dual careers: A multilevel model of entwined life courses ......................... 4

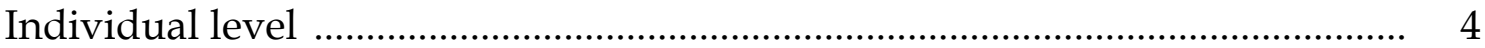

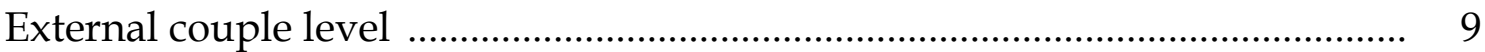

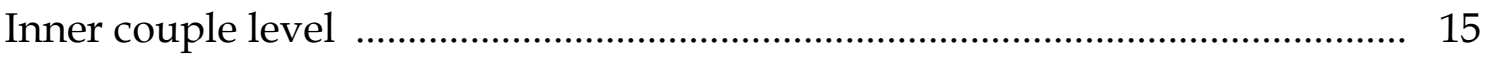

Conclusion: A life course and relational perspective on dual-careers research

References 



\section{Introduction}

Particularly among the highly educated, a persistent upward trend in female employment rates has characterized western industrialized countries in the last decades. Yet, strong gender inequalities persist as regard to career chances of equally - even high - qualified men and women. Worldwide, women are still underrepresented in executive/leading positions in both the private and public sector of the economy (United Nations 2001). In Germany, for example, the female labor force participation rate has increased from 46 percent in 1970 (FRG) to 66 percent in 2004 (Bothfeld et al. 2005: tables 3.A.1a,1c). But up to now only little more than one third of legislators, senior official and managers are women (Hausmann et al. 2007: 75), and only one sixth of the (associate and full) professors at German universities and colleges (Statistisches Bundesamt 2007a). And Germany represents no exception, but actually ranks at $8^{\text {th }}$ position (of 64) in the United Nations' Gender Empowerment measure (United Nations 2001: 214). ${ }^{1}$

Such gender gap in career chances can no longer be explained with differences in educational degrees attained by men and women, as gender differences in education have been enormously reduced in the course of the last three decades through educational expansion. In fact, in Germany today half of the university graduates are women (Statistisches Bundesamt 2006), and they complete their studies faster and with higher grades than their male fellow students (Krimmer et al. 2003, Stürzer 2005). Within the European Union (EU), women have even surpassed men and represent now 59 percent of university graduates (European Commission 2008: 14). ${ }^{2}$ Thus, potentially these women should have equal, if not higher, chances to follow a professional career. Why is this not the case?

We argue that gender inequalities in career chances are also attributable to the fact that the majority of highly educated women lives with an equally highly educated partner. According to a comparative study of thirteen countries, assortative mating has increased across birth cohorts and, with few exceptions, the likelihood to enter educational homogeneous marriages rises with

1 In comparison, the USA ranks at $10^{\text {th }}$ position. According to the Gender Empowerment measure (GEM), everywhere women are underrepresented in parliament, in administrative, managerial, professional and technical occupations (United Nations 2001). In EU member countries, only one third of managers and only $23 \%$ of national parliament members are women (European Commission 2008).

2 For women's advantage in college enrollment and completion in the USA and the reasons behind this trend see Buchmann and DiPrete $(2006,2008)$ as well as England and Lee (2006). 
higher levels of education (Blossfeld \& Timm 2003a). ${ }^{3}$ The rise of women's participation in (higher) education has thus increased the number of couples in which both partners have equal high qualifications. ${ }^{4}$ Especially for highly qualified women, the realization of dual careers - i.e., work/life models in which both partners are able to pursue professional occupations appropriate for their age and educational qualifications - becomes ever more important and represents an essential prerequisite for their own professional development.

Although in highly educated (homogeneous) couples the potential for entwining individual professional careers into dual careers is high, its achievement remains a great challenge and most frequently fails because of constraints on female careers. In 2004, for example, almost one third of German academically trained couples followed either a male one-earner or one-career model, and in two out of ten couples the woman pursued a professional occupation part-time, whereas her male partner did so full-time (Rusconi \& Solga 2007: 318). And Germany represents no special case: according to a comparative study of six western industrialized countries, in over one third of the couples the man is employed full-time, whereas his (female) partner is either not employed or works only part-time (Crompton 2006: 172). ${ }^{5}$

Because of different definitions used by scholars to identify dual-career couples, it is quite difficult to compare the occurrence of such an arrangement across countries, and even more so in a historical perspective (cf. Hiller \& Dyehouse 1987, Saraceno 2007). A review of the literature suggests, however, that

3 Country studies included Denmark, Flemish Belgium, France, Great Britain, Hungary, Italy, Israel, Slovenia, Spain, Sweden, The Netherlands, USA and West Germany. Birth cohorts vary among the countries and include individuals born before 1919 up to 1980 (Blossfeld \& Timm 2003b).

4 According to a German research, the proportion of female university graduates aged 30 to 49 - with an equally educated partner has remained quite constant around 50 percent, whereas the proportion of German male graduates with an equally academically trained partner has increased from 15 percent in 1971 to 33 percent in 2004. As a result, in 2004 almost 10 percent of all German couples both partners held an academic degree; in 1971 this share was only 1 percent (Rusconi \& Solga 2007: 313). According to a U.S. study, the proportion of married couples in which both partners held at least a bachelor's degree increased from about 7 percent in 1970 to 18 percent in 2000 (Schwartz \& Mare 2005: 629-630).

5 Data refers to 2002 and comparison included Britain, Finland, France, Portugal, Norway, and USA. Only in Finland less than 20 percent of the couples followed such "(neo-)traditionalist" arrangements, whereas the highest share (52 percent) is found in Britain (Crompton 2006: 172). A Northern American study that focused on middle-class dual-earner couples' work-hour strategies revealed that only 21 percent followed a "high commitment" strategy (i.e., both partners worked more than 45 hours). In the majority of the couples (38 percent) the man worked 45 hours and more, whereas the female partner worked less. (Moen \& Sweet 2003: 20). Couples in which both partners have high-prestige jobs, and thus can be considered dual-career rather than 'only' dual-earner couples, are three times more likely to follow the "high commitment" strategy (Moen \& Sweet 2003: 22). 
nowadays the incidence of dual-career arrangements does not surpass 30 percent. ${ }^{6}$ It is apparent that whereas dual-earner arrangements become increasingly widespread (Blossfeld \& Drobnič 2001a), dual-career couples remain a minority - even among the highly educated.

Following Phyllis Moen's "linked lives" idea, we will argue that the achievement or failure of dual-career arrangements is a "social-relational process" (Moen 2003a: 10) and that partners' lives are embedded with and influenced by each other. In particular, we will discuss how this entwining occurs, which processes at different levels play a role, and how these processes interact with each other. Finally, we will give some suggestions for further research.

Up to now, a systematic examination of the different factors and processes that shape entwined life courses and occupational careers in couples is lacking. So far, scholars have carried out research separately in different disciplines or fields of study, such as labor markets, human resources management, family and gender issues. However, they have rarely made an effort to integrate or connect their results and research foci. As a result, the different findings appear to coexist loosely next to each other and a complete picture of the various processes that influence couples' career chances is missing. The aim of this paper is to systematically incorporate the manifold research results by means of a multilevel analytical model, and thus to provide a systematic research overview regarding couples' opportunities and constraints of achieving dual-careers. And as a result, women's chances to pursue own professional careers.

6 According to German research on academically educated couples, only in less than a third of couples both partners were able to pursue full-time a professional occupation appropriate for their education level (Rusconi \& Solga 2007: 318). A Swiss study, which used a more narrow career definition, shows that in only 10 percent of couples both partners were able to follow (slow and high) upward careers (Levy et al. 2007: 280). This proportion is similar to the one found for Italy, on the basis of occupational classes of employed husbands and wives (Lucchini et al. 2007: 300). A Northern American study that focused on middle-class dual-earner couples revealed that in only 28 percent of these couples both partners had stable career pathways (characterized by full-time employment and few changes in employer or occupational status). In the majority (40 percent) of the couples the husband had a predominantly stable pathway, whereas the wife showed mainly an unstable career pattern (Williams \& Han 2003: 95). 


\section{Dual careers: A multilevel model of entwined life courses}

An examination of entwined life and work courses of men and women in a committed relationship requires going beyond the sole analysis of the individual characteristics of each partner. Rather it is necessary to include the analysis of general social and cultural conditions and institutional structures, in which couples make their decisions about both partners' occupational careers and family life.

In the following, we elaborate a multilevel analytical frame to entwined life courses in couples that accounts for both inner couple work/life management as well as external couple factors that structure careers. In our multilevel model, interdependent processes on the following three levels determine individual career chances of each partner, and as a result the likelihood of achieving a dual-career arrangement:

- Individual level: processes that influence career chances of each partner irrespective of the person's commitment to a partner.

- External couple level: processes connected to being committed to a partner that influence career chances of each partner.

- Inner couple level: processes concerning coordination and negotiation patterns within the couple as regard to employment, career and family that influence career chances of each partner.

On each of these three levels we can identify distinct factors that define and shape individual careers and, thus, couples' chances of achieving dual careers. In the following, we will elaborate on each of the three levels and integrate important research findings.

\section{Individual level}

The focus of this first level is on gender-specific processes that shape women's and men's chances on the labor market - independent of whether they are committed to a partner or not. There is an ample literature on these issues and a wide consent that gender inequality in employment and career chances is often the result of multidimensional occupational segregation.

First, there is substantial horizontal gender segregation in terms of fields of studies. In most countries, women are underrepresented in engineering, math and computer sciences and overrepresented in health/welfare and education fields (cf. Charles \& Bradley 2002). According to a comparative study of twelve European countries, the dissimilarity index for tertiary education ranges from 
27 percent (in the Netherlands) to 44.5 percent (in Austria) (Smyth 2002: 4-5). ${ }^{7}$ On EU average only 29 percent of scientists and engineers are women (European Commission 2008: 14). For the USA, scholars have revealed that whereas during the 1970s and early 1980s the enrollment of women into 'male dominated' subjects had increased (Jacobs 1995, England \& Li 2006), this "desegregation" trend has now stopped and horizontal segregation endures because fewer women enter male subjects and men still avoid "feminized" fields (England \& Li 2006). A widespread explanation for this divide is that genderspecific socialization processes influence the choice of individuals to select fields of studies that are regarded being socially acceptable for a person of one's own sex (Jacobs 1989, Lueptow et al. 2001, England 2005). ${ }^{8}$ On the one hand, gender appropriateness might refer to stereotypes of what is typically "masculine" (e.g., analytic thinking and accordingly math or sciences), and what is typically "feminine" (e.g., nurturing and teaching) (Jacobs 1995, Anker 1997). On the other hand, it might relate to the anticipation of traditional gender roles within the family - as (female) primary caregiver or as (male) primary breadwinner. Accordingly, women might avoid enrolling in fields of study that lead to professions perceived as being incompatible with a family (Ware \& Lee 1988), whereas men steer clear of devaluated (i.e. under-rewarded) female dominated subjects (England \& Li 2006).

Secondly, horizontal segregation goes hand in hand with different monetary rewards, labor market potentials, and career resources and, thus, vertical segregation. Generally, female dominated subjects are less rewarded on the labor market, and often lead to occupations with lower promotion chances, shorter career ladders, and a different range of activities in different sectors of the economy (Reskin 1993, Reskin \& Padavic 1994, Allmendinger \& Podsiadlowski 2001, Dressel 2005, England 2005, European Commission 2008). In addition, a German study suggests that in male dominated fields of studies and occupations professional success is less related to objective criteria of achievement (e.g., professional mobility, international experience, or further training), but rather to more informal, unspoken rules (Könekamp \& Haffner 2005, Haffner 2007). These entail normative expectations on professional commitment that demand an exclusive identification and engagement with the occupation, par-

7 This research included a comparison of Austria, Belgium, Finland, France, Greece, Hungary, The Netherlands, Romania, Slovakia Slovenia, Spain and Sweden (Smyth 2002). Germany has a large horizontal segregation, too. Women are underrepresented in natural sciences and engineering (in 2005, respectively 37 and 20 percent), and overrepresented in linguistic and humanities (in 2005, 70 percent cf. Statistisches Bundesamt 2007b: 27).

8 However, socialization processes are not limited to the early (pre-university) life, but "social pressures throughout the life cycle continually produce and reproduce the sexual division of labor" (Jacobs 1995: 83). At least for the U.S. there is some evidence that education institutions might reinforce gender segregation, as many women who initially enrolled in typically male fields of studies switch to typically female ones during the course of their studies (Jacobs 1989, 1995). 
ticularly in terms of long working hours and, in the private sector, the actual presence at the work place. ${ }^{9}$ Such a working culture expects and endorses a typically male work-centered biography with an uninterrupted career history, and a homemaker partner to take care of the family needs. Consequently such culture hinders, if not even excludes, individuals who are not willing or able to pursue such work-dominated life styles. Given the different private life commitments of men and women, and particularly the fact that women can hardly ever rely on a male homemaker partner, female graduates in male dominated fields of studies often have lower career chances than their male peers (Haffner 2007). For this reason, there is also some evidence that women have lower chances than men even in female dominated fields. As soon as women deviate from the male career track and propose somewhat different agendas the "doors in the profession begin to swing shut" (Swiss \& Walker 1993: 4, for masculine norms and practices in UK academia see Knights \& Richards 2003, for gender differences among art history PhDs in the US see Rudd et al. 2008).

As mentioned at the beginning of this paper, everywhere women are still underrepresented in executive/leading positions in both the private and public sector of the economy (United Nations 2001, Hausmann et al. 2007). This is a quite striking evidence of the persistent vertical segregation; i.e., women's concentration in lower levels of the professional hierarchy and their declining proportion every step up the career ladder. Taking again as an example Germany, in higher education institutions female professors constitute with about 15 percent not only a small minority (Statistisches Bundesamt 2007a), they are also most often appointed in lower professorships ranks and with lower salaries; for example as assistant professors or at technical colleges, rather than as full professors at universities (Stürzer 2005, Statistisches Bundesamt 2007b). Also in the private economy women are rather in middle management positions, but hardly in higher management (Holst 2005, Kleinert et al. 2006, Kleinert et al. 2007), and among the self-employed they have more often administrative responsibilities or less prestigious projects than executive positions (Holst 2005). Again Germany represents no exception, but ranks in European comparison on an average position (Holst 2005). ${ }^{10}$

9 Next to these general trends, there are nonetheless differences within male and female occupations. Because of their wider occupational options, such as selfemployment, computer scientists have more flexible working hours than chemists (Könekamp \& Haffner 2005), and psychologists more than physicians (Dettmer \& Hoff 2005).

10 In Germany, 11 percent of members in the highest decision-making bodies of the largest publicly quoted companies are women. A considerable higher share $(22$ percent) is found in Eastern countries (such as Slovenia and Lettland), but also in Norway and Sweden and the UK (16-18 percent). Southern countries rank below average, with the lowest share in Italy (2 percent) (Holst 2005: 50). Regarding management positions, Germany has 27 percent of female managers. Again, Eastern Europe has a higher share, whereas Nordic countries are in a middle position. Italy, but also Denmark, rank below average (Holst 2005: 51). 
Another widespread form of gender segregation is contractual segregation. Generally, women are overrepresented in fixed-term and part-time contracts (for European comparison see Petrongolo 2004, for Germany see Dressel 2005, for the UK see Thornley 2007). ${ }^{11}$ In academia, for example, women are employed more often than men as fixed-term (third-party) research staff or with a scholarship, rather than assistants or readers/lecturers (for the USA see Ezrati 1983, Bird \& Bird 1987, for Germany see Geenen 1994, Fuchs et al. 2001; Krimmer et al. 2003, for the UK see Knights \& Richards 2003). As result, women earn lower wages, 12 face more unsecure employment prospects, and restricted opportunities for professional development. Krimmer and colleagues (2003) have shown for Germany that although women obtain faster their academic degree and $\mathrm{PhD}$ than men, they are less likely and slower in completing a postdoctoral qualification (Habilitation); that in many fields of studies is a sine qua non for a professorship appointment. Rudd and colleagues (2008) have revealed for the U.S. that the majority of male art history PhDs but less than half of female PhDs achieved tenure 10 to 14 years after their doctorate. Partially the result of the different influence of marriage on men's and women's odds of tenure (Rudd et al. 2008).

The reasons behind such widespread occupational segregation are manifold, and can be subsumed in two major types of explanations (Anker 1997). According to labor supply explanations, in order to have time for childcare more women than men 'prefer' occupations with flexible hours or jobs that are relatively easy to interrupt (e.g., Hakim 2000). ${ }^{13}$ Yet, such occupations or worktime arrangements are often considered (or believed to be) incompatible with leading/executive positions (Lorber 1994). Other explanations focus on labor

11 In 2007, the share of women employees working part-time was about 31 percent in the EU (men: 8 percent), whereby the Netherlands had the highest female rate (75 percent), followed by Germany (46 percent) and the UK (42.5 percent) (European Commission 2008: 27). The share of female employees with temporary contracts was about 15 percent in the EU, the highest rate ( 31 percent) and gender gap can be found in Spain (European Commission 2008: 28).

12 In addition, worldwide there is still a substantial gender gap in wages also for similar work (Hausmann et al. 2007), and the gender divide increases with every step up the occupational ladder. For example in Germany: among the employees in highly qualified activities, women receive only 75 percent of the pre-tax hourly wages compared to men, among employees with executive/managerial functions, female pre-tax hourly earnings were only 57 percent of the male ones (data refers to West Germany in 2003, cf. Bothfeld et al. 2005: table 5.A.25).

13 According to Hakim, particularly in the two liberal societies, Britain and USA, female overrepresentation in lower-level occupations, in part-time and flexible working positions is attributable to the existence of three different work-lifestyles preferences among women (Hakim 2000: 6). Given that only a minority of women prioritizes their jobs in the same way as men do, men retain their dominance in the labor market (Hakim 2000). For a critique of Hakim's preference theory and contradicting British evidence see McRae (2003) and Crompton and Lyonette (2005). 
demand, i.e., employers' 'preference' regarding hiring women or men for particular occupations, different opportunities for promotion, and career development within firms (Anker 1997: 316). Thus, another cause for differences in employment and career prospects of women and men is a gender-biased behavior of employers based upon statistical discrimination processes (Reskin \& Padavic 1994, Anker 1997, Konrad \& Cannings 1997, England 2005). On the basis of traditional gender roles expectations, employers assume that on average men and women differ in their productivity, skills, etc., and are therefore less willing to hire and promote women. Particularly North American studies have shown that employers often judge women - even university graduates - as less career oriented than men, and expect them to reduce (if not even entirely quit) their professional engagement in favor of their family (Bird \& Bird 1987, MonkTurner \& Turner 1987, Bryant et al. 1988, Stroh \& Reilly 1999). ${ }^{14}$ According to a German research on psychologists and physicians, more women do indeed define professional success differently than men - namely as successful reconciliation of employment and family (Dettmer \& Hoff 2005). Yet, it is questionable whether this different definition should lead (and even justify) employers to believe that women are less professionally committed and/or less productive than men are. Rather this different definition might only be the result of women's dilemma to find private solutions for the reconciliation of employment and family life, an indication of their professional commitment, a strategy to 'have it all'.

Partly responsible is a definition and conception of 'successful careers' that is based on the (typically) male biography, with regard to temporal and flexible availability, timing and sequencing of career steps (Swiss \& Walker 1993, Knights \& Richards 2003, Jacobs \& Winslow 2004). A striking example thereof was the recourse on age and seniority as apparently gender-neutral promotion criteria in the past German public services law. It was not before 2005, that these criteria were replaced by likewise supposedly gender-neutral criteria: time spent in firm and in employment. However, these as well work at the advantage of men, who pursue uninterrupted careers more often than women do. But even meritocratic criteria such as achievement and productivity, e.g., the number of publications or experience in national and international firms, are in reality based upon the "time available" for career development and thus to some extent even reinforce the prevailing 'male' work pattern. Given the gender typical division of labor within families and, ensuing from contractual segregation, the poorer career-beneficial conditions faced by women, even gender-neutral constructs work against women and penalize them vis-à-vis male colleagues. In sum, employers' traditional gender-roles expectations and formal promotion criteria often work in favor of men reproducing and reinforcing occupational segregation.

14 For employers discrimination in German academia see Pfister (1998) and Engler (2001). 
Finally, informal segregation reinforces vertical and contractual segregation, often resulting in the well-known glass ceiling effect. Women are frequently excluded from informal professional networks (Reskin 1993: 254), in particular from high trust relationships. Therewith they have less opportunities of developing and enjoying business/professional confidence (Allmendinger et al. 2000); an essential prerequisite for professional integration, development and promotion within the organization - and possibly even beyond.

Horizontal, vertical, contractual, and informal gender segregation all systematically disadvantage women in comparison to men and result in unequal labor market and career chances of women and men. Such processes of producing gender inequality on the individual level lays down important premises for entwining processes on the external couple and inner couple level. Given that occupational gender segregation often results in unequal career prospects for male and female partners, at certain career or family phases that are (or appear to be) incompatible with two careers and a thriving family life, some couple might decide to prioritize the (male) career with be better prospects and scale back, or put on hold, the other (female) one. Like a self-fulfilling prophecy, this coordination strategy will in turn decrease the female partner's chances on the labor market because these women will more often display discontinuous work biographies and less strategic moves for the advancement of their own careers. Thus, occupational gender segregation is apt to increase gender inequality both at the individual level as well as within the couple. However, the occupational fields of both partners will determine the career prospects, the extent (if at all) and timing of geographical mobility necessary for career advancement for one or both partners, and which consequences each partner might face by declining relocation or moving in order to accommodate their partner's needs.

Whereas the mechanisms at individual level impinge on the professional development of all individuals irrespective of their private situation, the focus of the following, second level is on the particular processes individuals face as result of their being committed to a partner, and possibly children.

\section{External couple level}

In the course of industrialization, paid and unpaid labor increasingly have separated. This has led to a progressively large detachment of public and private spheres. Accordingly, modern labor market institutions are concerned with individuals only, relegating family life to the private domain and its reconciliation to a 'private' problem. Nonetheless (or for this very reason) several factors shape individual career chances owing to the fact that the person has a partner (and a family). The focus of this second level is therefore on processes that shape women's and men's chances on the labor market, as a result from their being committed to a partner. Above all, we consider now institutionalized 
gender roles beliefs, geographical ties motivated by family concerns, and rules regarding couples' (joint) employment.

Comparative research shows that couples' - and particularly wives' - employment patterns are closely related to country-specific employment structures and welfare regimes (Esping-Andersen 1991, 1999, Leira \& Saraceno 2008). These are the result of - but as well reproduce themselves - prevalent gender roles beliefs in the different societies. Roles ascriptions of "husband" and "wife" (Böhnisch 1999, Behnke \& Meuser 2005) are strongly connected to gender roles ascriptions of "mother" and "father". They shape male and female careers because they externally define how, and especially from whom, children should be reared. International research reveals that women can realize and negotiate with their partners an own employment and career only if they are able to externalize childcare and housework (Kirner \& Schulz 1992, Stephens 1999, Hochschild 2003). Consequently, female employment is challenged when external childcare is unavailable, the price too high, or the opening hours of childcare facilities inadequate (Hertz 1986). In international comparison, only the Nordic countries, Belgium, and France are really committed to a "de-familialization", whereas most welfare states do not actively engage in a "de facto reduction of the family welfare burden" (Esping-Andersen 1999: 55). Above all Austria and Germany are still encouraging the traditional male bread-winner model, especially in respect to an institutional discouragement of wives' employment (Esping-Andersen 1999: 65). Thus, conservative welfare states support mothers who give priority to family activities resulting in wives' economic dependence on their husbands and mothers' non-employment or part-time work. Differently, Mediterranean welfare states, with extremely low public provisions and strong familialism, encourage the polarization of couples between one-earner families and those who become dual-earner couples constraining their fertility. Differently, liberal welfare states do not intrude in the market forces and an increasing number of households shifts from domestic activities to paid work, whereas domestic and child care services are cheap(er) (especially as a result of immigration). Finally, social democratic welfare states, characterized by egalitarism, de-commodification and de-familialization, favor women's labor market participation and dual-earner households (Blossfeld \& Drobnič 2001b). In Nordic countries, there appears to be also a lower level of work-life conflict (Crompton 2006). Possibly also because, in international comparison, married or cohabiting men and women in these countries spend on average less hours for housework (Knudsen \& Wærness 2008). This indicates that a higher level of horizontal gender segregation in "egalitarian" welfare states (Charles 2003) does not necessarily lead to a male breadwinner model. Rather a large service sector, particularly in the public segment of the economy, and thereby an extremely well developed public provision of welfare services, above all childcare facilities, enhance female employment (Saraceno 1997) and thus couples' chances of achieving dual-earner if not even dual-career arrangements. 
According to a comparative research of EU member states, in BelgiumFlanders, Denmark, France, and Sweden the public and private childcare coverage rate for children under three surpasses 40 percent; French Belgium and in the Netherlands it is about 33 percent; whereas Austria, Germany, Greece, Italy and Spain with less than 10 percent score quite unfavorably (Plantenga et al. 2008: 35). In Germany, the relevance and institutionalization of traditional gender roles beliefs are clearly manifested by tax benefits for married couples (Ehegattenspiltting) ${ }^{15}$ and by lacking provision of public childcare. Especially in West Germany, the number of public facilities for children under three is still insufficient and the opening hours often do not even cover 'traditional' nine-tofive jobs (BMFSFJ 2006: 228). Thus, childcare facilities do not meet the needs and expectations of many highly qualified professionals. ${ }^{16}$ As a result, 80 percent of dual-earner families and 70 percent of single-parent families with children under three must rely upon alternative ("private") childcare solutions (Bien et al. 2007: 7) - a clear indication that the low provision by the state is not solely induced by a lack of demand. ${ }^{17}$ Although it might be the case that, in West Germany, only few parents take into consideration childcare outside the family during the child's first year, afterwards the demand for such childcare facilities increases. ${ }^{18}$ The inadequacy of childcare services is the result of, but as well reproduces institutionalized gender roles beliefs that conceive and depend upon mothers as primary caregivers. ${ }^{19}$ As discussed at the beginning of this section, Germany is a quite traditional welfare regime as regard to childcare policies and services.

15 Such tax benefit applies only for married couples and is especially advantageous for childless couples. Because of the progressive tax system, couples in which one partner has no income, typically male one-earner couples, have the greatest benefit.

16 In West Germany, only 10 percent of children under three (can) attend childcare services (the corresponding proportion in East Germany is 40 percent cf. Bien et al. 2007: 6). In addition, for every fifth child under three years and every sixth child aged three to six childcare opening hours do not (or only barely) cover parents' working hours (Bien et al. 2007: 12).

17 According to the same study, 84 percent of the non-employed mothers of children under three years report that they want an employment; for 55 percent of these women missing or inadequate childcare facilities were one of the reasons for being out of the labor force (Bien et al. 2007: 8).

18 Only 13 percent of parents would enroll a child to childcare before his/her first birthday. Differently, 31 percent of parents with one-year old child/ren and 60 percent of parents with two-year old child/ren would use childcare services (Bien et al. 2007: 9-10).

19 The necessity to increase the number of public childcare - particularly for children under three - has been (finally) recognized by the German government and a new policy aims at creating additional 230.000 childcare places until 2010 (Bundesregierung 2006: XXVII). 
Such traditional gender roles hold back women - at least temporarily - in their role as workers and professionals, and trigger even female university graduates into adopting a (three) phases model to reconcile family and professional development phases. Yet, as mentioned above, any work interruption or working hour reduction entails the risk of a more or less permanent professional setback because career requirements are often based on male (full-time) continuous careers and biographies.

Another factor that shapes employment and career chances are geographical ties. Generally, individuals committed to a family (a partner, and especially children) are less mobile geographically than singles (Kalter 1998, Stroh 1999, Green \& Canny 2003). However, especially for the higher educated, geographical mobility is an important element of career development (Deitch \& Sanderson 1987, Stroh 1999, Ackers 2004, Challiol \& Mignonac 2005). University graduates show higher mobility rates than lower qualified, and their moves are more often motivated by professional reasons (for Germany cf. Büchel 2000, Büchel et al. 2002). As a result, one major dual career dilemma for highly educated couples in which both partners (want to) pursue professional careers, is geographical mobility. Up to now, the solution of this dilemma is principally a private one; i.e., couples themselves have to handle how to reconcile careers' mobility requirements with, at the same time, family needs for stability. A frequent solution is to search for jobs in large metropolitan communities because the chances of finding two adequate positions are higher there than in medium-sized or smaller cities (for France see Lelièvre \& Bonvalet 1994, for the UK see Green 1995, for the USA see Shauman \& Xie 1996, Costa \& Kahn 2000). Thus, advantageous local labor market conditions are an essential prerequisite for resolving this dual-career dilemma. However, even large labor markets do not guarantee equal career chances (see previous section) and individuals who limit their job search to certain geographical areas might also reduce their career chances, as there might be better options elsewhere. Yet, women face higher risks. Owing to horizontal segregation, appropriate job openings in female dominated fields might be lacking or limited even in metropolitan areas. ${ }^{20}$ In sum, a commitment to a partner limits the options individuals have to pursue own careers via geographical mobility, and it influences the professional situation and career chances of the partner (Jürges 1998a). But women appear being penalized more than men (Kalter 1998, Boyle et al. 2001, Ackers 2004). Partially because women

20 As suggested by an Northern American study, many women however choose occupations "as nursing and primary education in anticipation of their future gender roles [...] as trailing wives who need to have a job that is in demand in any locality" (Cooke 2001: 339). At least in the case of schoolteachers, German research shows that horizontal segregation can be advantageous. These women can more easily manage geographical mobility - as 'tied movers' because of demands of their partner's careers - by means of ministerial agreements, than female partners employed in the private sector of the economy or as academics in universities (Solga \& Rusconi 2004). 
are often more concerned than men with 'meshing' or coordinating their careers with those of their partners (Matthews \& Matthews 1980, Bird \& Bird 1987, Monk-Turner \& Turner 1987, Pixley \& Moen 2003, Ackers 2004, Behnke \& Meuser 2005). As a result, they are more often "tied" mover or stayer; i.e., they reject more often job offers in other locations, or move more often in order to follow their partners rather than for their own career advancement.

With respect to rules regarding couples' (joint) employment, some developments have taken place in the course of the last decades. Employers increasingly face and have to deal with employees and candidates whose partners have own careers, rather than (female) homemakers willing to relocate in order to follow their partners (Harvey 1995, Stroh 1999, Challiol \& Mignonac 2005). Especially in the private economy, some larger firms have developed dualcareer policies in order to successfully recruit and retain qualified candidates (Domsch et al. 1989, Domsch \& Ladwig 1997, Domsch \& Krüger-Basener 1999, Stroh 1999, Schulte 2005). Particularly in the USA, higher education institutions have as well recognized the need of accommodating dual-career couples and about 24 percent of North American universities and colleges implemented a variety of dual career policies to support partners' job search (Wolf-Wendel et al. 2003: 17). ${ }^{21}$ In this respect, German academia is still trailing behind. But in the last years, the awareness for this problem has increased and - albeit not in an institutionalized manner - once confronted with this problem some higher education institutions offer different types of solutions to assist the spouse/ partner find employment; few even within the same university (about 10 percent cf. Solga \& Rusconi 2004, Vedder 2004).

In contrast to such dual career policies, that to some extent support, if not even enhance, the pursuit of dual careers, there are rules that severely constrain couples' career chances. Above all, anti-nepotism rules that forbid the employment of both partners in the same institution. Such regulations are a manifest example of how a commitment to a partner might indeed have a direct effect on the employment and career chances of individuals, because the recruitment (or rather rejection) criteria is not the person's qualification, experience, or aptness for the job, but his or more frequently her family status. North American research shows that especially in small labor markets, e.g. in academia or in small or isolated areas, official and covert anti-nepotism regulations are particularly detrimental to female careers. Such regulations often discriminate against women, because they are typically younger than their male partners and thus often apply in the same institution after their partners and/or with less bargain power (Arkin \& Dobrofsky 1978, Matthews \& Matthews 1980, Moore 1980, Dagg 1993, Swiss \& Walker 1993, Wilson 1996, Barnett \& Rivers 1998). In view

21 Of those without written or unwritten policies, however, only 15 percent reported they would do "nothing" to assist partner accommodation (Wolf-Wendel et al. 2003). Assistance ranges from career and placement services to temporary faculty fellowships, job sharing and, more rarely, creating tenure track positions (for an overview of dual career policies at U.S. universities cf. Rusconi 2002). 
of this discriminatory effect, and blatant contradiction to affirmative action measures, in the course of the 1970s the USA has dropped such anti-nepotism rules (Dagg 1993, Shoben 1997). ${ }^{22}$ In contrast, in Germany legal and covert antinepotism rules are still widespread in the public service and private economy. ${ }^{23}$

Another example of how a commitment to a partner constrains career chances is employers' prejudice against individuals who are in a commuter or living apart relationship. Particularly Northern American research provides evidence that employers often believe that these individuals are less flexible and might not give the best at work, or that they might quit the job as soon as they find a new one closer to where the partner lives (Taylor \& Lounsbury 1988, Hendershott 1995, Stroh 1999). Consequently, employers are less keen to hire and promote individuals who commute, and thus penalize individuals and especially women who have chosen such a private solution to the problem of reconciling a private/family life with mobility career requirements. ${ }^{24}$

Obviously, no policy will ever solve all the problems connected with being or wanting to be a dual career couple. Particularly Northern American research shows that even if firms or universities are willing to employ both partners, the realization of dual careers remains a difficult endeavor (Sekaran 1986, Smart \& Smart 1990, Wilson 1999). ${ }^{25}$ From a private point of view, an employment in the same institution might be advantageous, whereas from a professional point of view, it might entail a sub-optimal career development for one (or both) partner(s) compared to a position elsewhere. In addition, the 'trailing' partner might encounter some misjudgment or concerns as regard to his (but most often her) skills, qualifications, quality, and aptness for the job (Barnett \& Rivers 1998, Wilson 1999, Wolf-Wendel et al. 2003). Moreover, there is some evidence that when couples apply for two job openings at the same institution, employers offer lower salaries than for two comparably trained but unrelated professionals

22 However, there is some evidence that even nowadays they are sometimes informally put into effect (McNeil \& Sher 2001).

23 For example in Berlin a law from the year 1954 still applies that bans the employment of husbands and wives (and other relatives) at the same institution/organization in public service.. However, the consequences of such legal rules or even only covert reservations against couples' and particularly female partners' employment in the same institution have not yet been a central focus in European research.

24 A survey of German higher education institutions shows that appointment committees often have prejudices against candidates who commute (or plan to do so, once appointed for the job). Moreover it has also revealed that "commuting" female candidate face higher risk of being excluded from the short list (Solga \& Rusconi 2004). This gender bias is in part caused by traditional gender role expectations of the committee's members.

25 For Germany see Schulte $(2002,2005)$. 
(Matthews \& Matthews 1980, Ezrati 1983, Wilson 1999). ${ }^{26}$ This is especially the case for married female academics. Because of their lower bargain power as a result of their limited mobility, institutions often consider these women as 'captive' employees and offer them less advantageous positions (Ezrati 1983, Bird \& Bird 1987, Smart \& Smart 1990). Finally, once couples have found two acceptable positions, they might thereafter limit their geographical mobility and in the long run face the risk of achieving either only sub-optimal or short-lived dual careers.

How couples deal with these often conflicting career and family demands is the focus of the following, the third level: the inner couple coordination arrangements. Our basic assumption is that the inequality, the opportunities and constraints at the individual and external couple levels define the opportunities structures for couples and their coordination arrangements.

\section{Inner couple level}

Inner couple coordination patterns influence how men and women, who are committed to a partner, deal and adjust to the just described individual and external factors, and how they behave on the labor market. An overview of previous research leads to the distinction among three prevalent coordination patterns for entwining life courses in couples: the hierarchical, the individualistic and the egalitarian model.

The most common coordination strategy is the hierarchical model in which only one partner - often the man - has the career role, whereas the other partner - often the woman - supports $(t)$ his leading career through a primary responsibility for 'family matters'. 27 Even among academically trained couples, a common strategy is to follow the (male) partner with the better career prospects and opportunities resulting in a 'leading' career (Klein 1996, Hardill et al. 1997, Becker \& Moen 1999, Pixley \& Moen 2003); whereas the 'following' partner pursues an own occupation only within the context of the leading career's commitments and requirements. For example, women often interrupt their employment in order to follow their partner to a new location or to accommodate family needs, accept jobs with a lower income, or reject job offers which would require relocation or a full-time employment (Deitch \& Sanderson 1987, Jürges 1998b, Becker \& Moen 1999, Boyle et al. 2001, Ackers 2004). Such a hierarchical coordination strategy has self-reinforcing effects on reproducing gender differ-

26 Similar problems have been reported for job-sharing arrangements (Arkin \& Dobrofsky 1978, Moore 1980, Swiss \& Walker 1993, Barnett \& Rivers 1998, Wilson 1999).

27 German research shows that housewives (or wives with only a "secondary" employment) represent an important career resource for men; particularly in higher management (Böhnisch 1999, Böhnisch 2003) and in male dominated professions (Haffner 2007). For the USA see Hendershott (1995). 
ences in professional careers. Once women have scaled back and male careers have become predominant it is quite difficult to reverse this pattern. In order to 'revive' their careers women have to start at lower (usually precarious and less paid) positions. Consequently, male careers remain predominant for household finances and decision making (Kalter 1998, Becker \& Moen 1999, England 2005).

A frequent explanation for the prevalence of such hierarchical coordination strategy draws upon Blood and Wolfe's (1960) resource bargaining or social exchange perspective, according to which the division of labor within the family is the result of different bargain power, derived from resources, available to the partners. The partner with a more developed career (often the older man) has accumulated more resources and so a greater capacity to assert his/her professional interests than the less advanced partner (typically the younger woman). Following this line of reasoning, the chances of realizing dual careers are at risk in couples in which the partners have large status and income differences (Emerson 1976, Hawkes et al. 1980, Hood 1983). ${ }^{28}$ Negotiation models within the new household economics argue in a similar manner (cf. Becker 1991, Kalter 1998). It is in the best interest of both partners to maximize the profits that can be obtained by the leading career, also at the expense of the following career (that might result into no career for the following partner).

Both these theoretical perspectives acknowledge external factors - at the individual (e.g. occupational segregation) or external couple (e.g. mobility requirements) level - that generate gender differences on the labor market and that, on their part, shape couples' career decisions. However, both approaches conceptualize inner couple negotiation as gender-neutral processes that should apply irrespective of the gender of the older or more advanced partner. Yet, if it is true that gendered processes on the individual and external couple levels shape the opportunity structures for couples' coordination arrangements, in that for example more men than women are offered career opportunities that require relocation, it is also true that more female than male partners turn down such an opportunity (see also the previous section). Because both perspectives neglect a systematical comparison and analysis of untypical couples, they cannot explain why untypical couples, for example those in which the female partner is older and/or professionally more successful than the male partner, or

28 It is however unclear whether income or status differences play the greater role. Given the gender gap in wages, resulting from horizontal and contractual segregation, income differences between partners do not necessarily imply status or career differences. 
couples formed in later years, do not behave in a similar manner. ${ }^{29}$ In fact, there is some evidence that couples in which the women is the senior partner do not prioritize the (her) leading career to the same extent than age typical couples do (Hawkes et al. 1980, Bird \& Bird 1987, Solga et al. 2005). ${ }^{30}$ However, it remains unclear why this is the case; i.e., whether these couples are different with respect to their composition (e.g., as regard to children, or start of the relationship with respect to the career steps achieved by then), or whether these untypical couples have more egalitarian gender role beliefs than 'typical' couples.

Another inner couple coordination strategy is the individualistic model in which both partners independently pursue their own careers and the relationship itself plays a secondary role. This model is frequently linked to longdistance or commuter arrangements, with the goal of optimally structuring the career chances of both partners (Kilpatrick 1982). ${ }^{31}$ Yet, a commuter arrangement is frequently associated with additional burdens for the female partner. Because women are often the one staying at the principal (couple) residence, they have to fulfill a multitude of tasks that otherwise would have been characteristically shared with their male partners. Women who commute themselves manage to have a more egalitarian division of labor within the family, yet they are still disadvantaged vis-à-vis their partners because of the burdens associated with geographical mobility (Gross 1980, Schneider et al. 2002).

Most importantly, the birth of a child represents a major hurdle to this individualistic model, particularly when linked to commuter or living apart arrangements. On the one hand, the emotional and financial costs associated to a geographical distance between partners increase or become/appear unfeasible (Austin \& Pilat 1990, Hileman 1990). On the other hand, the birth of a child revitalizes typical/'traditional' gender role expectations. Female partners become mothers confronted with high expectations in terms of time availability for family needs, whereas male partners become fathers expected to ensure the financial resources for their family. The key difference between these two roles is that

29 For the USA there is some evidence that when women are more successful than their male partners this might strain the relationship, and that husbands adapt best when they are successful in their professional field, even if they earn less than their wives (Barnett \& Rivers 1998). Female strategies to avoid such conflicts are to 'over-benefit' husbands at home, downgrading their own skills and accomplishments, finding legitimate excuses to leave the labor market, or turning down interesting job offers (Sekaran 1986, Bird \& Bird 1987). For the U.K. see Evetts (1993).

30 In addition, a German research on academically trained couples reveals that even couples in which the female partner is at least 8 years younger (not older) than her partner, thus the age difference between partners is very large, have a higher chance to achieve dual careers than couples in which both partners are of similar age (Rusconi \& Solga 2007).

31 Some U.S. scholars characterize commuter couples as "female determined" (Hileman 1990), because couples often perceive this arrangement as being a response to 'her' needs (Gross 1980). And there is some evidence that commuting is more advantageous for women (Hileman 1990). 
the expectations associated with being a 'good' mother cannot be as easily "brushed aside" or sacrificed to accommodate professional demands, because they involve "being present with the children in a way that the construction of 'good fathering' (currently) does not " (Hardill \& van Loon 2007: 169). Several studies show that the acceptance of these role ascriptions is strongly dependent on the gender identities of both partners, and especially on that of the male partner (Hertz 1986, Bielby \& Bielby 1992, Levy \& Ernst 2002, Moen \& Sweet 2003, Behnke \& Meuser 2005, Schulz \& Blossfeld 2006). The individualistic coordination arrangement rests on the male partner's acceptance of a female career, and this only as long as his own career is not jeopardized by it (Hertz 1986). As soon as career/family conflicts arise gender roles expectations might be revitalized and often couples who initially started off as equal partners turn to more traditional hierarchical models (Becker \& Moen 1999, Levy \& Ernst 2002, Schulz \& Blossfeld 2006). Thus, at the birth of a child the career chances of both partners become an important (re-)negotiation issue within the couple. Childcare, housekeeping, and their organization often become primary female tasks, and couples negotiate public and private childcare and household aids as paid substitutions for the female partner. As discussed in more detail in the previous section, the availability and costs of childcare facilities and housekeeping aids play a decisive role for the endurance of such individualistic coordination arrangement in couples with children. Research shows that if couples are not able to 'outsource' such family tasks, female partners are the one who compromise, with often enduring negative consequences for their careers.

Particularly among the higher educated, a common strategy to avoid such career/family conflicts is to remain childless (Gilbert 1985), or to delay the birth of a child until it is compatible with the female career (Monk-Turner \& Turner 1987, Austin \& Pilat 1990, Swiss \& Walker 1993, Costa \& Kahn 2000, Altucher \& Williams 2003). In Germany, for example, female university graduates are twice as much childless than less qualified women, but they are also more often childless than equally educated men are (Huinink 1995, for gender differences among German professors see Krimmer et al. 2003, for gender differences among U.S. assistant professors see Jacobs \& Winslow 2004). Yet, there is some evidence that 'late' motherhood does not shelter from all negative consequences; rather the gender bias imposed by the birth of a child follows women up the career ladder (Swiss \& Walker 1993). In addition, at least for Northern America academia, it appears that obtaining "tenure first, kids later" is rarely a feasible strategy because most assistant professors are too old to delay much longer the birth of a child (Jacobs \& Winslow 2004: 149).

The egalitarian model is the third - albeit less widespread - strategy of inner couple coordination. In these couples both partners give an equal importance to their professional careers and their family, and both make compromises in their careers (or are willing to do so) for the benefit of their family or for an optimal combination of career opportunities for both partners (Becker \& Moen 1999, Hardill et al. 1999, Costa \& Kahn 2000, for Germany see Behnke \& Meuser 2005, 
Dettmer \& Hoff 2005). Because these couples do not fully take advantage of their career potentials, both partners face the risk of a limited professional development. Owing to employers' expectation of gender roles congruence, men who do not follow work-dominated lifestyles but reduce their professional commitment in order to accommodate family demands might even be more strongly penalized than women (as the latter are to some extent expected to do so) (Cooper \& Lewis 1993, Konrad \& Cannings 1997). ${ }^{32}$ Given the often family unfriendly career requirements, institutional doing gender, as well as a lack of 'role models' of egalitarian inner couple negotiation and management, following a egalitarian coordination strategy might therefore have some drawbacks. According to a German research, such an arrangement is more likely to succeed in couples formed in early years, i.e., already during college/ university, possibly because these couples had agreed upon the goal of achieving egalitarian dual careers before the start of their actual careers (Dettmer \& Hoff 2005). Yet, up to now there has been no systematical comparison with couples formed considerably later (e.g., after both partners have already achieved independently successful careers, or after the dissolution of a previous relationship). As a result, it remains unclear whether 'older' couples rather have better chances to achieve or follow this egalitarian coordination model and why this might be the case. ${ }^{33}$

Most importantly, couples' coordination models are not a 'once for all' fixed strategy. A German study revealed, for example, that couples often do not conceive distance or commuter arrangements as permanent coordination strategy, but rather only as a transitional phase in the life course (Schneider et al. 2002). Coordination strategies are contingent upon, and thus might change during the course of a relationship. To name just a few examples, the birth of a child or one partner's career opportunity in a new location, might become turning points at which couples re-negotiate their coordination strategies. The switch from one strategy to another might in turn, change one's or both partners' (relative) position on the labor market and thus the opportunities and constraints at the individual and external couple levels that influence individual and couples' career chances and define the opportunities structures for couples' coordination arrangements. For example, once children are born, couples who started as equal partners and followed an individualistic coordination arrangement might de-

32 Moreover, there is some evidence that men who relocate in order to 'follow' their female partners experience higher stress levels; partially because of traditional role expectations that the female (and not the male) partner should be the trailing spouse (Stroh 1999). For an overview of the difficulties faced by 'caring' fathers in the Netherlands see Duindam (1999).

33 For example, 'older' couples might be less keen to give up an own career (or to prioritize professional development at the expense of a happy relationship), because they have learned from previous experiences and are now more aware of the risks, or because both partners have equal resources and thus are equally able to assert their interests. 
cide to reduce the labor market engagement of one partner, especially if the (public) provision of childcare is scarce or inadequate. Because of gender role expectations and, ensuing from occupational gender segregation, the often worse labor market position and/or career prospects of the female partner, couples will often decide to (temporary) put on hold the female - rather than male - career. When female partners are ready to return to their jobs (and again cultural expectations and the availability of childcare facilities will influence this timing and whether it is acceptable to switch from a stay-at-home mom to a part-time or even full-time employed mom), what were initially only horizontal differences might have developed into vertical and contractual differences between partners. This is the case when, for example, women return in a part-time position or when the occupational culture expects and endorses a workcentered biography with an uninterrupted career history and penalizes those individuals who have interrupted or reduced their professional engagement. In the meantime, promotions or new professional opportunities could arise for their male partners with an uninterrupted career history. At the next turning point, for example a job offer for the male partner's career, the problem arises anew. However, couples will have to make a new decision taking into consideration the new situation. Couples thus face both old and new mechanisms. Some couples might decide to go against the gender typical expectations and give the female partner a chance to regain her territory on the labor market and therefore reject the job offer. Others might choose to prioritize the more advanced (male) career and follow this opportunity. Some of these couples, likely those with young children, might move the entire family in the new location where the female partner will have to search for a new job; others might decide to establish separate residences and commute in order to keep the female employment. These short examples show that coordination strategies do not need to be an 'either-or alternative'; rather couples might use different strategies at different stages of their career and family cycle. 


\section{Conclusion: A life course and relational perspective on dual-careers research}

In sum, processes at the individual, external and inner couple levels do not simply coexist side by side, rather they mutually interact with each other (Glaser \& Strauss 1967, Monk-Turner \& Turner 1987, Moen \& Wethington 1992). Professional requirements are often incompatible with the pursuit of two careers, a thriving relationship, and parenthood. Couples frequently (have to) compromise. As a result of prevalent gender role expectations and occupational gender segregation, most often women and mothers are the one who scale back or put their careers on hold. Because of external factors shaping careers and professional expectations, these often only temporary compromises (might) end in long-term negative consequences for the female career and dual careers might fail permanently. Given the some what different definition of professional success by men and women (Dettmer \& Hoff 2005), motherhood however should not be automatically interpreted as re-traditionalization. As noted by a British research on dual career couples, most women see motherhood as an "inalienable part of their being" (Hardill \& van Loon 2007: 176). Thus, female reconciliation strategies might represent a way to 'have it all'. Moreover, the birth of a child might only be the indirect cause of women's lower career commitment or even complete withdrawal from the labor market. Because of the difficulties of simultaneously combining two careers, gender discrimination, the so-called glass ceiling effect, and the biological clock ticking louder for women than for men, some women might postpone the achievement of their professional goals and in the meantime realize their family goals. As previously discussed, this strategy has, however, some self-reinforcing effects and women's employment often remains a secondary career. Because of diverse work cultures and alternative career paths, different professions allow however for different opportunities for reconciling a career and a family, and thus for dualcareers.

Our multilevel framework thus implies a dynamic relation within and among the three different levels. Each career step of both partners and every new family phase are apt to call for renewal negotiation. Only few scholars, however, have adopted such a research perspective and these dynamic processes have received too little attention when studying the dual-career couple/family. It is thus necessary to consider the opportunities and constraints of achieving dualcareers in a life course perspective. Couples' tasks, responsibilities, priorities and career requirements all vary according to the different stages of the relationship and of the individual careers. A life course perspective allows linking the different goals and inner couple strategies to the different dilemmas partners face at various stages of their careers and family cycles. The goals and ambitions of both partners as well as couples' coordination strategies change in the course of professional and family development, in response to changes in the family (e.g. 
the birth of a child) and through the outcomes of the coordination strategies negotiated within the couple (cf. Nock 1998, Moen 2003b, Dettmer \& Hoff 2005). Thus, a life course perspective on the interdependent processes on the just described individual, external couple, and inner couple levels helps understanding under which circumstances couples' arrangements become irreversible or not.

In addition, different constellations of the partners' individual characteristics within the couple might mediate these dynamic processes and their outcomes for female and dual careers. As discussed in more detail elsewhere (Solga \& Wimbauer 2005, Rusconi \& Solga 2007), scholars have so far not paid enough attention to the couple as unit of analysis and thus underestimated the importance of the relation of certain characteristics between partners in determining the failure or success of achieving dual careers. Further research should take into account not only the age, career stage, income, professional field, sector of the economy, etc. of each partner as career determinants, but the constellation of these characteristics within the couple, too. For example, the constellation of professional fields within the couple might shape couples' chances of achieving dual-careers with different types of coordination arrangements. Whereas couples in which at least one partner pursues a profession with a wide range of occupational or geographical options might be able to achieve dual-careers even following a hierarchical coordination model over longer period of time, this might not be the case for couples with another professional constellation. Similarly, the career stages of both partners might determine the willingness and possibilities employers have to help them deal with dual-career issues. At least for academia, there is some evidence that employers are more willing to employ the partner of a "star", rather than of a still unknown person (Wolf-Wendel et al. 2003: 157). Yet, if the partner has as well established career or a senior position, the costs can be very high. Thus, whereas couples' bargaining power increases as they step up the career ladder, it is easier (and cheaper) for employers to help couples in which the 'following' partner (often the woman) is either younger, or has scaled back, or interrupted her career in order to accommodate the needs of the family, and thus has not yet reached a similar high rank position (cf. Solga \& Rusconi 2004).

Our systematic overview discloses also several unresolved research questions. We still know very little, on how the processes behind couples' formation influence couples' arrangements. Which partner an individual seeks for and chooses - e.g., with regard to age, career conceptions, desire to have children as well as when and under which conditions a person is ready to enter a committed relationship might co-determine (or might be endogenous to) the preferred gender arrangement in the couple, and the chances and options of pursuing and maintaining egalitarian inner couple coordination strategies. But also what individuals have experienced in previous relationships might play a role in the search for a new partner and in the compromises they are ready to accept. Perhaps not only the 'negotiated' inner couple arrangement is decisive for the 
realization of dual-careers, but also the factors behind the timing and choice for a certain partner. Couples with an egalitarian coordination strategy might be successful because next to (or even independently from) their career resources, they present specific partner constellations, that enable them to maintain longterm such an arrangement and diminish the risk of a re-traditionalization.

Future research should also include in a more systematic manner the analysis of couples with atypical constellations, such as those in which the woman is older than the man, or in which partners do not exhibit the gender typical horizontal segregation. Although scholars often assume a gender-specific effect of the restrictions found on all three just discussed different levels, they have rarely systematically compared typical and atypical couples. To some extent, their gender-specific findings might be therefore the result of a composition effect, because 'typically' women work in less rewarded professions, earn less money, are younger than their male partners, and are the one who take care of the children. But it is still an unsettled question whether 'atypical' male partners and couples enjoy fewer restrictions and take different decisions than typical couples, and thus whether gender-specific restrictions indeed hinder dualcareers.

Scholars also frequently regard external couple conditions as a matter of course, and individuals' actions as an execution of institutional requirements. Couples' own contributions and their resisting potential on the basis of their coordination strategies are given too little consideration. Processes of re-traditionalization, once children are born, seem to occur almost automatically. Which individual, external, and inner couple factors determine whether couples prefer and follow traditional or egalitarian coordination arrangements remain unaccounted for. Previous research analyzes only the consequences of certain given (typically hierarchical) inner couple coordination arrangements. A systematic investigation on the dual-career chances of couples in which man puts his career on hold or scales back is lacking. It is therefore still an unsettled question whether a (even only temporarily) unequal division of labor is generally connected with negative consequences, or only when women scale back.

A systematic analysis and comparison of dual-career demands in different occupational fields and disciplines is missing, too. Up to now, very dissimilar studies, with regard to their methods and research foci, have looked at professional fields leading to contradicting findings on the advantages and disadvantages of professional homogeneity or heterogeneity in couples. Therefore, it is hardly possible to meaningfully compare the different results and reach a reliable conclusion of how the constellation of the professional fields and sectors within the couple influences the chances of achieving dual-career arrangements.

Finally, there is a growing sociological interest in the "rush hour of life", the life span of women (and men) between their $25^{\text {th }}$ and $35^{\text {th }}$ birthday during which they have to make manifold professional and familial decisions, all at the same time. Yet, scholars have paid insufficient attention to both the flexibility of inner couple coordination strategies in the course of a relationship, as well as to 
the fluidity of relationships during the life course (i.e., the succession of being single and in a relationship) in interdependence with the biographical-temporal career sequencing of both partners. The question of whether there are general, age-specific, and career phases-specific demands on the long-term realization of dual-careers can be adequately resolved only if the just described interdependent processes are included and analyzed systematically, not only during a specific (rush-hour) life phase.

The aim of our paper was to systematically incorporate the diverse research findings regarding opportunities and constraints of achieving dual-careers in a multilevel analytic model in order to provide a more complete understanding of the different mechanisms behind couples' "linked lives". In addition, we have disclosed several unresolved questions for future research. 


\section{References}

Ackers, L. (2004). Managing relationships in peripatetic careers: Scientific mobility in the European Union. Women's Studies International Forum, 27(3): 189-201.

Allmendinger, J., Fuchs, S. and Stebut, J. v. (2000) Should I Stay or Should I Go? Mentoring, Verankerung und Verbleib in der Wissenschaft. Empirische Ergebnisse einer Studie zu Karriereverläufen von Frauen und Männern in Instituten der Max-Planck-Gesellschaft. In J. Page and R. J. Leeman (Eds.), Karriere von Akademikerinnen. Bedeutung des Mentoring als Instrument der Nachwuchsförderung. Zürich: Verein Feministische Wissenschaft Schweiz, pp. 33-48.

Allmendinger, J. and Podsiadlowski, A. (2001) Segregation in Organisationen und Arbeitsgruppen. In B. Heintz (Ed.), Geschlechtersoziologie. Opladen: Westdeutscher Verlag, pp. 276-307.

Altucher, K. A. and Williams, L. B. (2003) Family Clocks: Timing Parenthood. In P. Moen (Ed.), It's about time: Couples and careers. Ithaca: ILR Press, pp. 49-59.

Anker, R. (1997). Theories of occupational segregation by sex: An overview. International Labour Review, 136(3): 315-339.

Arkin, W. and Dobrofsky, L. R. (1978) Job Sharing. In R. Rapoport, R. N. Rapoport and J. M. Bumstead (Eds.), Working Couples. London: Routledge \& Kegan Paul, pp. 122-137.

Austin, A. E. and Pilat, M. (1990). Tension, Stress, and the Tapestry of Faculty Lives. Academe, 76(January-February): 38-42.

Barnett, R. C. and Rivers, C. (1998). She Works/He Works: How Two-Income Families are Happy, Healthy, and Thriving, Cambridge, Mass.: Harvard University Press.

Becker, G. S. (1991). A treatise on the family, Cambridge, Mass.: Harvard Univiversity Press.

Becker, P. E. and Moen, P. (1999). Scaling Back: Dual-Earner Couples' Work-Family Strategies. Journal of Marriage and the Family, 61(4): 995-1007.

Behnke, C. and Meuser, M. (2005) Vereinbarkeitsmanagement. Zuständigkeiten und Karrierechancen bei Doppelkarrierepaaren. In H. Solga and C. Wimbauer (Eds.), "Wenn zwei das Gleiche tun." Ideal und Realität sozialer (Un)Gleichheit in Dual Career Couples. Opladen: Barbara Budrich Verlag, pp. 123-139.

Bielby, W. T. and Bielby, D. D. (1992). I will follow him: family ties, gender-role beliefs, and reluctance to relocate for a better job. American Journal of Sociology, 97(5): 1241-1267.

Bien, W., Rauschenbach, T. and Riedel, B. (2007). Wer betreut Deutschlands Kinder? DJIKinderbetreuungsstudie, München: Deutsches Jugendinstitut.

Bird, G. W. and Bird, G. A. (1987). In Pursuit of Academic Careers: Observations and Reflections of a Dual-Career Couple. Family Relations, 36(January): 97-100.

Blood, R. O. J. and Wolfe, D. M. (1960). Husbands and wives: The Dinamics of Married Living, Illinois: The Free Press of Glencoe.

Blossfeld, H.-P. and Drobnič, S. (2001a). Careers of couples in contemporary societies: From male breadwinner to dual earner families. Oxford: Oxford University Press.

Blossfeld, H.-P. and Drobnič, S. (2001b). Theoretical Perspectives on Couples' Careers. In H.-P. Blossfeld and S. Drobnič (Eds.), Careers of Couples in Contemporary Societies: From Male Breadwinner to Dual Earner Families. Oxford: Oxford University Press, pp. 16-50. 
Blossfeld, H.-P. and Timm, A. (2003a). Assortative Mating in Cross-National Comparison: A Summary of Results and Conclusions. In H.-P. Blossfeld and A. Timm (Eds.), Who marries whom? Educational systems as marriage markets in modern societies. Dordrecht: Kluwer, pp. 331-342.

Blossfeld, H.-P. and Timm, A. (2003b). Who marries whom? Educational systems as marriage markets in modern societies. European studies of population. Dordrecht: Kluwer.

Böhnisch, T. (1999). Gattinnen: die Frauen der Elite, Münster: Westfälisches Dampfboot.

Böhnisch, T. (2003). Karriereressource Ehefrau - Statusressource Ehemann. In R. Hitzler and M. Pfadenhauer (Eds.), Karrierepolitik. Beiträge zur Rekonstruktion erfolgsorientierten Handelns. Opladen: Leske + Budrich, pp. 173-187.

Bothfeld, S., Klammer, U., Klenner, C., Leiber, S., Thiel, A. and Ziegler, A. (2005). WSIFrauenDatenReport 2005. Handbuch zur wirtschaftlichen und sozialen Situation von Frauen., Berlin: edition sigma.

Boyle, P., Cooke, T. J., Halfacree, K. and Smith, D. (2001). A Cross-National Comparison of the Impact of Family Migration on Women's Employment Status. Demography, 38(2): 201-213.

Bryant, E. S., Mey, B. J. V. and Burgess, N. J. (1988). Coemployed Spouses. Differences, Strategies, and Discrimination. Journal of Family Issues, 9(4): 496-517.

Büchel, F. (2000). Tied Movers, Tied Stayers: The Higher Risk of Overeducation Among Married Women in West Germany. (Reprint). In S. S. Gustafsson and D. E. Meulders (Eds.), Gender and The Labour Market. Econometric Evidence of Obstacles to Achieving Gender Equality. London/New York: Macmillan Press/St. Martin's Press, pp. 133-146.

Büchel, F., Frick, J. R. and Witte, J., C. (2002). Regionale und berufliche Mobilität von Hochqualifizierten. Ein Vergleich Deutschland - USA. In L. Bellmann and J. Velling (Eds.), Arbeitsmärkte für Hochqualifizierte. Nürnberg: IAB, pp. 207-244.

Buchmann, C., DiPrete, T. and McDaniel, A. (2008). Gender Inequalities in Education. Annual Review of Sociology, 34: 319-337.

Buchmann, C. and DiPrete, T. A. (2006). The Growing Female Advantage in College Completion: The Role of Family Background and Academic Achievement. American Sociological Review, 71(4): 515-541.

Bundesministerium für Familie Senioren Frauen und Jugend [BMFSFJ] (2006). Familie zwischen Flexibilität und Verlässlichkeit. Perspektiven für eine lebenslaufbezogene Familienpolitik. Siebter Familienbericht. Berlin.

Bundesregierung (2006). Stellungnahme der Bundesregierung zum Siebten Familienbericht. In Bundesministerium für Familie Senioren Frauen und Jugend [BMFSFJ] (Ed.), Familie zwischen Flexibilität und Verlässlichkeit. Perspektiven für eine lebenslaufbezogene Familienpolitik. Siebter Familienberich. Berlin, pp. XXIII-XXXV.

Challiol, H. and Mignonac, K. (2005). Relocation decision-making and couple relationships: a quantitative and qualitative study of dual-earner couples. Journal of Organizational Behavior, 26(3): 247-274.

Charles, M. (2003). Deciphering Sex Segregation. Vertical and Horizontal Inequalities in Ten National Labor Markets. Acta Sociologica, 46(4): 267-287.

Charles, M. and Bradley, K. (2002). Equal but Separate? A Cross-National Study of Sex Segregation in Higher Education. American Sociological Review, 67(4): 573-599.

Cooke, L. P. (2001). "Impact of dual careers on average family size: comparison of 11 countries". 2001-05. An Integrated Research Infrastructure in the Socio.Economic Sciences. 
Cooper, C. L. and Lewis, S. (1993). The Work Place Revolution. Managing Today's DualCareer Families, London: Kogan Page.

Costa, D. L. and Kahn, M. E. (2000). Power Couples: Changes in the Locational Choice of the College Educated, 1940-1990. The Quarterly Journal of Economics, 115(4): 1287-1315.

Crompton, R. (2006). Employment and the family. The reconfiguration of work and family, Cambridge: Cambridge University Press.

Crompton, R. and Lyonette, C. (2005). The New Gender Essentialism - Domestic and Family 'Choices' and their Relation to Attitudes. British Journal of Sociology, 56(4): 601-620.

Dagg, A. I. (1993). Academic Faculty Wives and Systemic Discrimination - Antinepotism and "Inbreeding". The Canadian Journal of Higher Education, 23(1): 1-18.

Deitch, C. H. and Sanderson, S. W. (1987). Geographic Constraints on Married Women's Careers. Work and Occupations, 14(4): 616-634.

Dettmer, S. and Hoff, E.-H. (2005). Berufs- und Karrierekonstellationen in Paarbeziehungen: Segmentation, Integration, Entgrenzung. In H. Solga and C. Wimbauer (Eds.), "Wenn zwei das Gleiche tun." Ideal und Realität sozialer (Un)Gleichheit in Dual Career Couples. Opladen: Barbara Budrich Verlag, pp. 53-75.

Domsch, M., Krüger-Basener, M. and Schneble, A. (1989). Zeitliche Abstimmungsprobleme der Laufbahnentwicklung von "Dual Career Couples". In H. Hax, W. Kern and H.-H. Schröder (Eds.), Zeitaspekte in betriebswirtschaftlicher Theorie und Praxis. 50. Wissenschaftliche Jahrestagung des Verbandes der Hochschullehrer für Betriebswirtschaft e.V. Stuttgart: C.E. Poeschel, pp. 331-348.

Domsch, M. E. and Krüger-Basener, M. (1999). Personalplanung und -entwicklung für Dual Career Couples (DCCs). In L. v. Rosenstiel, E. Regner and M. E. Domsch (Eds.), Führung von Mitarbeitern. Handbuch für erfolgreiches Personalmanagement. Stuttgart: Schäffer-Poeschel, pp. 547-558.

Domsch, M. E. and Ladwig, A. (1997). Dual Careers Couples (DCC'S). Einsichten und Aussichten für Karrierepaare und Unternehmen. Report Psychologie, 22(4): 310315.

Dressel, C. (2005). Erwerbstätigkeit - Arbeitsmarktintegration von Frauen und Männern. In W. Cornelißen (Ed.), Gender-Datenreport - Kommentierter Datenreport zur Gleichstellung von Frauen und Männern in der Bundesrepublik Deutschland. München: im Auftrag des Bundesministeriums für Familie, Senioren, Frauen und Jugend, pp. 99-158.

Duindam, V. (1999). Men in the Household: Caring Fathers. In L. McKie, S. Bowlby and S. Gregory (Eds.), Gender, Power and the Household. London/New York: Macmillan Press/St. Martin's Press, pp. 43-59.

Emerson, R. (1976). Social exchange theory. Annual Review of Sociology, 2: 335-362.

England, P. (2005). Gender Inequality in Labor Markets: The Role of Motherhood and Segregation. Social Politics, 12(2): 264-288.

England, P. and Li, S. (2006). Desegregation Stalled: The Changing Gender Composition of College Majors, 1971-2002. Gender and Society, 20(5): 657-677.

Engler, S. (2001). "In Einsamkeit und Freiheit"? Zur Konstruktion der wissenschaftlichen Persönlichkeit auf dem Weg zur Professur, Konstanz: UVK-Verlagsgesellschaft.

Esping-Andersen, G. (1991). The three worlds of welfare capitalism, Princeton, NJ: Princeton University Press.

Esping-Andersen, G. (1999). Social foundations of postindustrial economies, Oxford: Oxford University Press. 
European Commission (2008). Report on equality between women and men - 2008, Bruxelles: European Communities.

Evetts, J. (1993). Careers and Partnerships: The Strategies of Secondary Headteachers. The Sociological Review, 41(2): 302-327.

Ezrati, J. B. (1983). Personnel Policies in Higher Education: A Covert Means of Sex Discrimination? Educational Administration Quarterly, 19(4): 105-119.

Fuchs, S., Stebut, J. v. and Allmendinger, J. (2001). Gender, Science, and Scientific Organizations in Germany. Minerva, 39(2): 175-201.

Geenen, E. M. (1994). Blockierte Karrieren: Frauen in der Hochschule, Opladen: Leske + Budrich.

Gilbert, L. A. (1985). Men in Dual-career Families: Current Realities and Future Prospects, Hillsdale, N.J.: Erlbaum.

Glaser, B. G. and Strauss, A. L. (1967). The discovery of grounded theory: Strategies for qualitativ research, Chicago: Aldine Publishing.

Green, A. E. (1995). The Geography of Dual Career Households: A Research Agenda and Selected Evidence from Secondary Data Sources for Britain. International Journal of Population Geography, 1(1): 29-50.

Green, A. E. and Canny, A. (2003). Geographical mobility: family impacts, Bristol: Policy Press.

Gross, H. E. (1980). Dual-Career Couples Who Live Apart: Two Types. Journal of Marriage and the Family, 42(3): 567-576.

Haffner, Y. (2007). Mythen um männliche Karrieren und weibliche Leistung, Opladen: Barbara Budrich Verlag.

Hakim, C. (2000). Work-Lifestyle Choices in the 21st Century. Preference Theory, New York: Oxford University Press.

Hardill, I., Dudleston, A. C., Green, A. E. and Owen, D. W. (1999). Decision Making in Dual-Career Households. In L. McKie, S. Bowlby and S. Gregory (Eds.), Gender, Power and the Household. London/New York: Macmillan Press/St. Martin's Press, pp. 192-206.

Hardill, I., Green, A. E., Dudleston, A. C. and Owen, D. W. (1997). Notes and Issues. Who Decides What? Decision Making in Dual-Career Households. Work, Employment \& Society, 11(2): 313-326.

Hardill, I. and van Loon, J. (2007). Individualization and 'identity risks' in dual-career households. In D. Perrons, C. Fagan, L. McDowell, K. Ray and K. Ward (Eds.), Gender Divisions and Working Time in the New Economy: Changing Patterns of Work, Care and Public Policy in Europe and North America. Cheltenham: Edward Elgar, pp. 162-177.

Harvey, M. G. (1995). The impact of dual-career families on international relocations. Human Resources Management Review, 5(3): 223-244.

Hausmann, R., Tyson, L. D. and Zahidi, S. (2007). "The Global Gender Gap Report". World Economic Forum, Geneva, Switzerland. (www.weforum.org/pdf/ gendergap/report2007.pdf)

Hawkes, G. R., Nicola, J. and Fish, M. (1980). Young Marrieds: Wives' Employment and Family Role Structure. In F. Pepitone-Rockwell (Ed.), Dual-Career Couples. Beverly Hills/London: Sage, pp. 75-89.

Hendershott, A. B. (1995). Moving for Work. The Sociology of Relocating in the 1990s, Lanham, MD: University Press of America, Inc.

Hertz, R. (1986). More Equal than Others: Women and Men in Dual-career Marriages, Berkeley: University of California Press. 
Hileman, S. (1990). The "Female-Determined Relationship": Personal and Professional Needs of Academic Women in Commuter Marriages. In L. B. Welch (Ed.), Women in Higher Education. Changes and Challenges. New York: Praeger, pp. 119-125.

Hiller, D. V. and Dyehouse, J. (1987). A case for banishing "dual-career marriages" from the research literature. Journal of Marriage and the Family, 49(4): 787-795.

Hochschild, A. R. (2003). The Second Shift, London: McGaw-Hill Book Co.

Holst, E. (2005). Frauen in Führungspositionen: massiver Nachholbedarf bei großen Unternehmen und Arbeitgeberverbänden. DIW-Wochenbericht, 72(3): 49-56.

Hood, J. (1983). Becoming a two-job family, New York: Praeger.

Huinink, J. (1995). Warum noch Familie? Zur Attraktivität von Partnerschaft und Elternschaft in unserer Gesellschaft, Frankfurt/Main: Campus Verlag.

Jacobs, J. A. (1989). Revolving doors: sex segregation and women's careers, Stanford, Calif.: Stanford University Press.

Jacobs, J. A. (1995). Gender and Academic Specialties: Trends among Recipients of College Degrees in the 1980s. Sociology of Education., 68(2): 81-98.

Jacobs, J. A. and Winslow, S. E. (2004). The academic life course, time pressure and gender inequality. Community, Work \& Family, 7(2): 143-161.

Jürges, H. (1998a). Beruflich bedingte Umzüge von Doppelverdienern. Eine empirische Analyse mit Daten des SOEP. Zeitschrift für Soziologie, 27(5): 358-377.

Jürges, H. (1998b). Einkommen und berufliche Situation von Doppelverdienern nach Umzügen. Mitteilungen aus der Arbeitsmarkt- und Berufsforschung, 31(2): 234-243.

Kalter, F. (1998). Partnerschaft und Migration. Zur theoretischen Erklärung eines empirischen Effektes. Kölner Zeitschrift für Soziologie und Sozialpsychologie, 50(2): 283309.

Kilpatrick, A. C. (1982). Job Change in Dual-Career Families: Danger or Opportunity? Family Relations, 31(3): 363-368.

Kirner, E. and Schulz, E. (1992). Das "Drei-Phasen-Modell" der Erwerbsbeteiligung von Frauen - Begründung, Norm und empirische Relevanz. In N. Ott and G. Wagner (Eds.), Familie und Erwerbstätigkeit im Umbruch. Berlin: Duncker \& Humblot, pp. 17-55.

Klein, T. (1996). Der Altersunterschied zwischen Ehepartnern. Ein neues Analysemodell. Zeitschrift für Soziologie, 25(5): 346-370.

Kleinert, C., Kohaut, S., Brader, D. and Lewerenz, J. (2007). Frauen an der Spitze. Arbeitsbedingungen und Lebenslagen weiblicher Führungskräfte, Frankfurt/Main: Campus Verlag.

Kleinert, C., Kohaut, S. and Zirngibl, M. (2006). IAB-Führungskräftestudie - Die gläserne Decke. IAB Forum, 2: 6-11.

Knights, D. and Richards, W. (2003). Sex Discrimination in UK Academia. Gender, Work and Organization, 10(2): 213-238.

Knudsen, K. and Wærness, K. (2008). National Context and Spouses' Housework in 34 Countries. European Sociological Review, 24(1): 97-113.

Könekamp, B. and Haffner, Y. (2005). Ein Balanceakt? Dual Career Couples in den Berufsfeldern der Natur- und Ingenieurwissenschaften. In H. Solga and C. Wimbauer (Eds.), "Wenn zwei das Gleiche tun." Ideal und Realität sozialer (Un-)Gleichheit in Dual Career Couples. Opladen: Barbara Budrich Verlag, pp. 77-100.

Konrad, A. M. and Cannings, K. (1997). The Effects of Gender Role Congruence and Statistical Discrimination on Managerial Advancement. Human Relations, 50(10): 1305-1328. 
Krimmer, H., Stallmann, F., Behr, M. and Zimmer, A. (2003). "Karrierewege von ProfessorInnen an Hochschulen in Deutschland". Institut für Politikwissenschaft, Münster. (www.wissenschaftskarriere.de)

Leira, A. and Saraceno, C. (2008). Childhood: changing contexts. In A. Leira and C. Saraceno (Eds.), Childhood: changing contexts. Bingley: Emerald, pp. 1-24.

Lelièvre, E. and Bonvalet, C. (1994). A Compared Cohort History of Residential Mobility, Social Change and Home-ownership in Paris and the Rest of France. Urban Studies, 31(10): 1647-1665.

Levy, R., Bühlmann, F. and Widmer, E. (2007). Dual and single career couples in Switzerland: Exploring partners' trajectories. Zeitschrift für Familienforschung, 19(3): 263-289.

Levy, R. and Ernst, M. (2002). Lebenslauf und Regulation in Paarbeziehungen: Bestimmungsgründe der Ungleichheit familialer Arbeitsteilung. Zeitschrift für Familienforschung, 14(2): 103-131.

Lorber, J. (1994). Paradoxes of gender, New Haven, CT: Yale Univ. Pr.

Lucchini, M., Saraceno, C. and Schizzerotto, A. (2007). Dual-earner and dual-career couples in contemporary Italy. Zeitschrift für Familienforschung, 19(3): 290-310.

Lueptow, L. B., Garovich-Szabo, L. and Lueptow, M. B. (2001). Social Change and the Persistence of Sex Typing: 1974-1997. Social Forces, 80(1): 1-36.

Matthews, J. R. and Matthews, L. H. (1980). Going Shopping: The Professional Couple in the Job Market. In F. Pepitone-Rockwell (Ed.), Dual-Career Couples. Beverly Hills/London: Sage, pp. 261-281.

McNeil, L. and Sher, M. (2001). "Dual-Science-Career Couples: Survey Results". (www. physics.wm.edu/ sher/survey.html)

McRae, S. (2003). Constraints and Choices in Mothers' Employment careers: a Consideration of Hakim's Preference Theory. British Journal of Sociology, 54(3): 317-338.

Moen, P. (2003a). Introduction. In P. Moen (Ed.), It's about time: Couples and careers. Ithaca: ILR Press, pp. 1-14.

Moen, P. (2003b). It's about time: Couples and careers. Ithaca: ILR Press.

Moen, P. and Sweet, S. (2003) Time Clocks: Work-Hour Strategies. In P. Moen (Ed.), It's about time: Couples and careers. Ithaca: ILR Press, pp. 18-34.

Moen, P. and Wethington, E. (1992). The Concept of Family Adaptive Strategies. Annual Review of Sociology, 18: 233-251.

Monk-Turner, E. and Turner, C. G. (1987). Dual Career Academic Couples: Analysis of Problems and a Proposal for Change. Women and politics, 6(3): 43-55.

Moore, D. M. (1980). Equal Opportunity Laws and Dual-Career Couples. In F. Pepitone-Rockwell (Ed.), Dual Career Couples. Beverly Hills/London: Sage, pp. 229240.

Nock, S. L. (1998). Turn-Taking as Rational Behavior. Social Science Research, 27(3): 235244.

Petrongolo, B. (2004). Gender Segregation in Employment Contracts. Journal of the European Economic Association, 2(2-3): 331-345.

Pfister, G. (1998). The Struggle for Balance: The Career of a German University Professor. In M. David and D. Woodward (Eds.), Negotiating the Glass Ceiling: Careers of Senior Women in the Academic World. London: The Falmer Press, pp. 35-47.

Pixley, J. E. and Moen, P. (2003). Prioritizing Careers. In P. Moen (Ed.), It's about time: Couples and careers. Ithaca: ILR Press, pp. 183-200. 
Plantenga, J., Remery, C., Siegel, M. and Sementini, L. (2008). Childcare services in 25 European Union member states: the Barcelona targets revisited. In A. Leira and C. Saraceno (Eds.), Childhood: changing contexts. Bingley: Emerald, pp. 27-53.

Reskin, B. (1993). Sex Segregation in the Workplace. Annual Review of Sociology, 19: 241270.

Reskin, B. F. and Padavic, I. (1994). Women and Men at Work, Thousand Oaks: Pine Forge Pr.

Rudd, E., Morrison, E., Sadrozinski, R., Nerad, M. and Cerny, J. (2008). Equality and Illusion: Gender and Tenure in Art History Careers. Journal of Marriage and the Family, 70(1): 228-238.

Rusconi, A. (2002). "“What can universities do?” Dual-career policies at American universities". Arbeitsbericht der Arbeitsgruppe "Wissenschaftspolitik". Die Junge Akademie, Berlin. (www.diejungeakademie.de/ag/wissenschaftspolitik/dual_ career)

Rusconi, A. and Solga, H. (2007). Determinants of and obstacles to dual careers in Germany. Zeitschrift für Familienforschung, 19(3): 311-336.

Saraceno, C. (1997) Family Change, Family Policies and the Restructuring of Welfare. In OECD (Ed.), Family, Market and Community. Equity and Efficiency in Social Policy. Paris: OECD, pp. 81-100.

Saraceno, C. (2007). Introduction to the special issue: Dual-career couples. Zeitschrift für Familienforschung, 19(3): 255-262.

Schneider, N. F., Limmer, R. and Ruckdeschel, K. (2002). Berufsmobilität und Lebensform: sind berufliche Mobilitätserfordernisse in Zeiten der Globalisierung noch mit der Familie vereinbar? Stuttgart: Kohlhammer.

Schulte, J. (2002). Dual-career couples: Strukturuntersuchung einer Partnerschaftsform im Spiegelbild beruflicher Anforderungen, Opladen: Leske + Budrich.

Schulte, J. (2005). Dual Career Couples und ihre Koordinierungsarrangements aus der Sicht der Unternehmen. In H. Solga and C. Wimbauer (Eds.), "Wenn zwei das Gleiche tun." Ideal und Realität sozialer (Un)Gleichheit in Dual Career Couples. Opladen: Barbara Budrich Verlag, pp. 241-261.

Schulz, F. and Blossfeld, H.-P. (2006). Wie verändert sich die häusliche Arbeitsteilung im Eheverlauf. Eine Längsschnittstudie der ersten 14 Ehejahre in Westdeutschland. Kölner Zeitschrift für Soziologie und Sozialpsychologie, 58(2): 23-49.

Schwartz, C. R. and Mare, R. D. (2005). Trends in Educational Assortative Marriage from 1940 to 2003. Demography, 42(4): 621-646.

Sekaran, U. (1986). Dual-career families, San Francisco: Jossey-Bass.

Shauman, K. A. and Xie, Y. (1996). Geographic Mobility of Scientists: Sex Differences and Family Constraints. Demography, 33(4): 455-468.

Shoben, E. W. (1997). From Antinepotism Rules to Programs for Partners: Legal Issues. In M. A. Ferber and J. W. Loeb (Eds.), Academic Couples. Problems and Promises. Urbana and Chicago: University of Illinois Press, pp. 226-247.

Smart, M. S. and Smart, R. C. (1990). Paired Prospects: Dual-Career Couples on Campus. Academe, 76: 33-37.

Smyth, E. 2002. "Gender Differentiation and Early Labour Market Integration across Europe". Arbeitspapiere: 46. Mannheimer Zentrum für Europäische Sozialforschung, Mannheim. (www.mzes.uni-mannheim.de/fs_publikationen_d.html)

Solga, H. and Rusconi, A. (2004). Deutsche Hochschule und ihr ambivalentes Verhältnis zu Doppelkarrieren in Akademikerpartnerschaften. In G. Vedder (Ed.), Familiengerechte Hochschule: Analysen, Konzepte, Perspektiven. Frankfurt a.M.: HertieStiftung, pp. 64-89. 
Solga, H., Rusconi, A. and Krüger, H. (2005). Gibt der ältere Partner den Ton an? Die Alterskonstellation in Akademikerpartnerschaften und ihre Bedeutung für Doppelkarrieren. In H. Solga and C. Wimbauer (Eds.), "Wenn zwei das Gleiche tun." Ideal und Realität sozialer (Un-)Gleichheit in Dual Career Couples. Opladen: Barbara Budrich Verlag, pp. 27-52.

Solga, H. and Wimbauer, C. (2005). "Wenn zwei das Gleiche tun." Ideal und Realität sozialer (Un-)Gleichheit in Dual Career Couples. Eine Einleitung. In H. Solga and C. Wimbauer (Eds.), "Wenn zwei das Gleiche tun." Ideal und Realität sozialer (Un-) Gleichheit in Dual Career Couples. Opladen: Barbara Budrich Verlag, pp.

Statistisches Bundesamt (2006). Tabelle: Frauenanteile in verschiedenen Stadien der akademischen Laufbahn (Stand:18.10.2006).

Statistisches Bundesamt (2007a).. Frauenanteil bei Professoren steigt auf 15\%. Pressemitteilung, Nr. 279.

Statistisches Bundesamt (2007b). Hochschulen auf einen Blick, Wiesbaden: Statistisches Bundesamt.

Stephens, J. (1999). A Fight for Her Time: Challenges Facing Mothers who Work in Hospital Medicine. In L. McKie, S. Bowlby and S. Gregory (Eds.), Gender, Power and the Household. London/New York: Macmillan Press/St. Martin's Press, pp. 99-115.

Stroh, L. K. (1999). Does Relocation Still Benefit Corporations and Employees? An overview of the literature. Human resource management review, 9(3): 279-308.

Stroh, L. K. and Reilly, A. H. (1999) Gender and Careers. Present Experiences and Emerging Trends. In G. N. Powell (Ed.), Handbook of Gender $\mathcal{E}$ Work. Thousand Oaks, Calif.: Sage, pp. 307-324.

Stürzer, M. (2005). Bildung, Ausbildung und Weiterbildung. In W. Cornelißen (Ed.), Gender-Datenreport - Kommentierter Datenreport zur Gleichstellung von Frauen und Männern in der Bundesrepublik Deutschland. München: im Auftrag des Bundesministeriums für Familie, Senioren, Frauen und Jugend, pp. 21-97.

Swiss, D. J. and Walker, J. P. (1993). Women and the Work/Family Dilemma. How Today's Professional Women Are Finding Solutions, New York: John Wiley \& Sons.

Taylor, A. S. and Lounsbury, J. W. (1988). Dual-Career Couples and Geographic Transfer: Executive Reactions to Commuter Marriage and Attitude Toward the Move. Human Relations, 41(5): 407-424.

Thornley, C. (2007). Working Part-Time for the State: Gender, Class and the Public Sector Pay Gap. Gender, Work and Organization, 14(5): 454-475.

United Nations (2001). Human Development Report 2001. Making new technologies work for human development, Oxford: Oxford University Press.

Vedder, G. (2004). Familiengerechte Hochschule: Analysen, Konzepte, Perspektiven. Frankfurt a.M.: Hertie-Stiftung.

Ware, N. C. and Lee, V. E. (1988). Sex Differences in Choice of College Science Majors. American Educational Research Journal, 25(4): 593-614.

Williams, S. and Han, S.-K. (2003). Career Clocks: Forked Roads. In P. Moen (Ed.), It's about time: Couples and careers. Ithaca: ILR Press, pp. 80-97.

Wilson, R. (1996). Weary of Commuter Marriages, More Couples in Academe Make Career Sacrifices to Be Together. The Chronicle of Higher Education, 20(9): 10-11.

Wilson, R. (1999). The Frustrating Career of the 'Trailing Spouse'. The Chronicle of Higher Education, A 12(March 19).

Wolf-Wendel, L., Twombly Susan B. and Rice Suzanne (2003). The two-body problem: dual-career-couple hiring policies in higher education, Baltimore: Johns Hopkins University Press. 


\section{Books published by members of the research unit "Skill Formation and Labor Markets"}

(only available from commercial retailers)

\section{8}

Mayer, Karl Ulrich; Heike Solga (Eds.) (2008): Skill Formation - Interdisciplinary and Cross-National Perspectives. New York: Cambridge University Press

Söhn, Janina (2008): Die Entscheidung zur Einbürgerung. Die Bedeutung von Staatsbürgerschaft für AusländerInnen in der Bundesrepublik Deutschland Analysen zu den 1990er-Jahren. Saarbrücken: VDM Verlag Dr. Müller

\section{7}

Baethge, Martin; Heike Solga; Markus Wieck (2007): Berufsbildung im Umbruch - Signale eines überfälligen Aufbruchs. Berlin: Friedrich-Ebert-Stiftung. (auch online verfügbar: http://library.fes.de/pdf-files/stabsabteilung/04258/ studie.pdf)

Martens Kerstin, Alessandra Rusconi and Kathrin Leuze (eds.) (2007): New Arenas of Educational Governance - The Impact of International Organizations and Markets on Educational Policymaking. Houndmills, Basingstoke: Palgrave

\section{6}

Rusconi, Alessandra (2006): Leaving the Parental Home in Italy and West Germany: Opportunities and Constraints. Aachen: Shaker Verlag

\section{5}

Solga, Heike (2005): Ohne Abschluss in die Bildungsgesellschaft. Die Erwerbschancen gering qualifizierter Personen aus ökonomischer und soziologischer Perspektive. Opladen: Verlag Barbara Budrich

Solga, Heike; Christine Wimbauer (Hg.) (2005): Wenn zwei das Gleiche tun ... - Ideal und Realität sozialer (Un-)Gleichheit in Dual Career Couples. Opladen: Verlag Barbara Budrich

\section{4}

Hillmert, Steffen; Ralf Künster; Petra Spengemann; Karl Ulrich Mayer (2004): Projekt "Ausbildungs- und Berufsverläufe der Geburtskohorten 1964 und 1971 in Westdeutschland“. Dokumentation, Teil 1-9 (Materialien aus der Bildungsforschung No. 78). Berlin: Max-Planck-Institut für Bildungsforschung 


\section{Discussion Papers Research Unit "Skill Formation and Labor Markets"}

(available via Informations- und Kommunikationsreferat, Wissenschaftszentrum Berlin, Reichpietschufer 50, 10785 Berlin or download http://www.wzb.eu/publikation/)

\section{8}

SP I 2008-501

Justin J.W. Powell, Heike Solga, Internationalization of Vocational and Higher Education Systems - A Comparative-Institutional Approach, 49 p.

\section{SP I 2008-502}

Anja P. Jakobi, Alessandra Rusconi, Opening of Higher Education? A Lifelong Learning Perspective on the Bologna Process, $32 \mathrm{p}$.

\section{SP I 2008-503}

Janina Söhn, Bildungschancen junger Aussiedler(innen) und anderer Migrant(inn)en der ersten Generation. Ergebnisse des DJI-Jugendsurveys zu den Einwandererkohorten seit Ende der 1980er-Jahre, 37 p.

SP I 2008-504

Lisa Pfahl, Legitimationen schulischer Aussonderung. Eine Rekonstruktion des Lernbehinderungsdiskurses im 20. Jahrhundert in Deutschland, $42 \mathrm{p}$.

SP I 2008-505

Alessandra Rusconi, Heike Solga, A Systematic Reflection upon Dual Career Couples, $32 \mathrm{p}$. 